\title{
Investigating the Relationship between School Level and a School Growth Mindset
}

\author{
Janet Hanson (Corresponding author) \\ Department of Educational Leadership, Montana State University (MSU) \\ 457 Reid Hall, Bozeman, Montana, USA \\ $\&$ \\ Educational Leadership Department, Azusa Pacific University \\ P.O. Box 7000, Rm 137, Azusa, CA 91702-7000, USA \\ Tel: 1-(626)-815-5375Ｅ-mail: jhason@apu.edu

\begin{abstract}
William Ruff
Department of Educational Leadership, Montana State University (MSU)

457 Reid Hall, Bozeman, Montana, USA
\end{abstract}

Tel: 1-(406)-994-4182Ｅ-mail: wruff@montana.edu

\begin{abstract}
Arthur Bangert
Department of Educational Leadership, Montana State University (MSU)

115 Reid Hall, Bozeman, Montana, USA
\end{abstract}

Tel: 1-(406)-994-7424 E-mail: abangert@montana.edu

Received: September 20, 2016 Accepted: October 21, 2016

Published: November 3, 2016

doi:10.5296/jei.v2i2.10052 URL: http://dx.doi.org/10.5296/jei.v2i2.10052

\begin{abstract}
This study explored the relationship between school level and the psychosocial construct of a growth mindset school culture. Data was collected on the What's My School Mindset (WMSM) Survey from a stratified random sample of PK-12 faculty and administrators $(\mathrm{n}=$
\end{abstract}


347 ) in 30 schools across a large northwestern state. The overarching research question was, "Is there a relationship between school level and a school's growth mindset?" Results revealed a significant decrease in the WMSM mean between elementary school level and high school level participant self-reports. Therefore, the results of this study could be used to create opportunities for faculty dialogue and reflection to changes perspectives, inform future practice, provide realistic ways to implement change by using research-based evidence to challenge assumptions; and give sound reasons for new practices.

Keywords: Implicit theories, School culture, School level, Student transitions

\section{Introduction}

This study is the first to explore the effect of school level on faculty perceptions of their school growth mindset culture, or the belief in their teachers' ability to help all students grow and learn. Growth mindset theory contributes psychosocial perspectives on improving student motivation and achievement. Teacher beliefs and implicit theories influence teaching behaviors that have been shown to influence student academic behaviors and directly affect student transition success and completion rates (Blackwell, Trzesniewski, \& Dweck, 2007; Dweck, Chiu, \& Hong, 1995; Eccles \& Midgley, 1989; Farrington et al., 2012). Teachers with growth mindsets have been shown to develop positive psychosocial skills in students leading to increases in student choices to engage in academic behaviors that explain increased school outcomes. Using dialogical processes of a school growth mindset culture may result in organizational improvements and increased teacher skills that support all students to grow and learn (Esses, Haddock, \& Zanna, 1993).

The unidimensional construct of a school growth mindset culture consists of three sub-factors; collaborative planning, shared leadership, and open communication \& support (Hanson, Bangert \& Ruff, 2016). Growth mindset is an implicit theory grounded in social cognitive theory and the psychosocial theory of personal and collective efficacy (Bandura, 2001; Dweck \& Leggett, 1988; Hanson, 2015). For this study the psychosocial construct of a school growth mindset culture was the outcome measure and school level was the independent variable. The overarching question explored in this study was, "Is there a relationship between school level and a school growth mindset culture as measured by the WMSM scale?"

A goal of this study was to provide an alternative lens to view the processes of student learning across school transitions such as elementary to middle, middle to high school, and high school to college and work. Akkerman and Bakker (2011) identified a difference in worldviews between secondary teachers and students. Data on malleable variables of school culture that vary with school level could be useful for administrators to begin dialogues with faculty regarding their perceptions, beliefs, and implicit theories (mindsets) (Blackwell, 2012; Dweck, 2002, 2010; Hoy, Tarter, \& Kottkamp, 1991; Tarter \& Hoy, 2004). Engaging in difficult dialogues is one of the essential practices for changing institutional practices and building institutional capacity in continuous improvement processes (D. Smith, personal communication, July 18, 2015). A recommendation for promoting student learning during transitions was building relationships and initiating dialogues to overcome sociocultural 
differences between teachers and their new students (Eccles \& Midgley, 1989; Middleton \& Baartman, 2013).

Using data collected on the WMSM school growth mindset survey, teachers can quantify their beliefs about their school culture (espoused theories) and compare the results to their actual behaviors (theories-in-use) (Argyris \& Schon, 1996; Mindset Works, Inc., 2015a-2015c; Ruff, 2002). Recurring use of the WMSM scale can provide feedback on the impact of interventions in a school's culture over time. High school faculty can explore possible reasons if differences exist in their school growth mindset mean between elementary and middle school levels, and challenge themselves to learn more about developing psychosocial skills in students. This may result in an increase in the faculty's collective belief in their ability to help all students learn and grow.

\subsection{Definitions}

Social Cognitive Theory (SCT): This theory provides a framework to explain the way individuals learn and behave through a triad of reciprocal influences from observing the behavior of others, influences in their social environment, and their own internal cognitive and physiological factors (Bandura, 2001).

Individual mindset: This construct was developed in the foundational research of Dweck (1986) on individual personality theory. Individual mindset is defined as a psychosocial concept of attitudes, or beliefs, about how the world works that resultantly influence the individual's behaviors and decisions.

Academic mindset: This construct was described by Farrington et al. (2012) as "beliefs, attitudes, or ways of perceiving oneself in relation to learning and intellectual work that support academic performance" (p. 28). The four distinct academic mindsets include beliefs; of belonging; that one can grow through effort; that one can succeed at the classroom tasks; and that the classroom work required has value. The four constructs of the academic mindset have been operationalized on the Project for Educational Research that Scales (PERTS) scale (Hanson, 2015; Hanson, in progress b; PERTS, 2014a, 2014b).

Boundary crossing: is "a person's transitions and interactions across different sites," (Suchman, 1994, p. 25 in Middleton \& Baartman, 2013).

School growth mindset culture: This concept describes a culture with a, "common vision, sharing knowledge, support, and resources," (Blackwell, 2012, para. 6-10). Three subfactors have been identified through quantitative survey validation of the WMSM scale as collaborative planning, shared leadership, and open communication \& peer support (Hanson et al., 2016).

Enabling School Structures: Hoy and Sweetland (2001) explained "enabling school structures should be places where professional relations are open, collegial, supportive, and empowering" (p. 317). Tarter and Hoy (2004) provided empirical evidence that collective efficacy in an enabling school structure explains improved school outcomes. 


\subsection{Theoretical Framework}

This study explored the theories of organizational learning, growth mindset in public schools, and boundary crossing. Dialogical processes of boundary crossing and relative autonomy (a variable of self-efficacy theory) have been shown to influence student learning and engagement (Bandura, 2001; Briceño, 2013; Corrigan \& Frith, 1976; Lacey, 1970; Mays, 1965; McGrew, 2011; Shor \& Freire, 1987; Spector, 1988; Wenger, 1998; Willis, 1977/1981; Yeo, 2005). Akkerman and Bakker (2011) explained that "all learning involves boundaries" (p. 132, 133). Boundary theory has more recently been used in social theory to explore "marginal and decentered discourses of power" (Edwards \& Fowler, 2007 in Akkerman \& Bakker, p. 135).

Recent literature in social theory described a multiple dimensional model of the individual mind connected to others in ways that continuously construct and reconstruct the identity through dialogical processes (Dweck, 1999, Wenger, 1998). The relational influence of teacher beliefs, their social responsiveness and their interpersonal behaviors with students has been shown to influence student transition success. How the social dimension of knowledge construction influences a student's choice to engage learning has been described in Vygotsky's $(1962,1978)$ and Bandura's $(1977,1986,1989,1997,2001)$ research on social cognitive theory. An example of this can be seen in Zimmerman's (1989) definition of student self-regulated learning: self-regulated learning is a process in which learners actively participate in their own learning in terms of metacognition, motivation and action. Successful self-regulated learners must use a varied assortment of tools to motivate and guide their own learning. All learners proactively seek out information when needed and take necessary steps to master this learning and perceive themselves as thinking, feeling, and acting on their own learning initiatives (Cheng, 2011).

Haslam, Reicher, and Platow (2011) highlighted the interplay of identity, politics and leadership. Questioning assumptions is an essential element in organizational learning (Argyris, 1999), and organizational learning is essential in improving schools' educational processes (Hall \& Hord, 2015). Yet, many of the tacit beliefs, layers of assumptions in need of questioning, are integrated with identity, political ideology, and acted upon in decision making. If we are to provide schooling that truly facilitates the success of all students, we must think and act creatively in constructing and applying effective school theories and practices (Capper \& Green, 2013). Through the development of new tools to question existing theory and validate new organizational theories, a broader understanding may emerge to better clarify the social influences that impact students' construction of knowledge and their identities as learners (Oakes, Welner, \& Renée, 2015). This study attempts to contribute to this conversation in the hopes of providing empirical evidence that student success may be impacted by differences in a school's growth mindset; measured as the teachers' beliefs about their school's ability to help all students learn and grow.

\section{School Transition Effects}

As transitioning students experience changing school contexts, they can demonstrate withdrawal behaviors, such as reduced academic engagement, resulting in a drop in academic 
performance. Reduced academic behaviors include absenteeism, incomplete homework, and failure to study (Blackwell, Trzesniewski, \& Dweck, 2011; Dweck, 2012; Eccles, Lord, \& Midgley, 1991). Multiple studies showed student course failure during transition years in high school predicted school dropouts more than student grades. Allensworth and Easton (2005) reported students' chances of dropping out of high school increased by $30 \%$ if they failed one semester course in the first year of high school (Farrington et al., 2012, p. 59).

Students in school level transitions are learning how to relate to changes in norms and values, as well as developing their new identities in the new context (Akkerman \& Bakker, 2011, p. 138). At the time students are transitioning to middle and high schools they are experiencing increased psychological sensitivity due to cognitive changes in adolescence that increase their awareness of their social situation, self, and others. Student self-conceptions arise such as the belief that if one has to work hard it reflects poorly on one's abilities compared to others (Farrington et al., 2012, p. 55). This belief has been studied in the growth mindset research and reported in the literature as a malleable variable that can be influenced through improvements in a school's growth mindset culture (Dweck, 2008; Gay, 2010).

\subsection{Teacher Skills at Transition Sites}

Teachers in middle and high schools were reported as having fewer skills than teachers in elementary schools to address student psychosocial factors needed to develop engagement in school. For example, secondary level teachers tended to reward ability rather than effort. They also demonstrated increased control over students compared to elementary levels, increased whole class and group work emphasizing social comparison, and used a higher standard for grading performance. Middle and high school teachers also used judgments about student attitudes and behaviors as direct factors when calculating student grades, not just student learning outcomes (Austin \& McCann, 1992; Cross \& Frary, 1999). Teachers at the secondary level also used teaching practices that reduced student autonomy and had fewer teacher-student relationships (Blackwell et al., 2007; Spector, 1988). Many secondary level teachers lack skills for developmentally appropriate responses to students' needs during transition years; thus contributing to reduced student academic engagement and to reduced pro-social behaviors (Eccles \& Wigfield, 2002; Farrington et al., 2012, p. 63).

The middle and high school context included faculty use of behaviorist-style strategies to motivate disengaged students with threats of failure, reduced monitoring, and lack of feedback to students. These methods contributed to reductions in student perceptions of internal locus of control and withdrawal from engagement in school (Farrington et al., 2012, p. 49,64$)$. In contrast, faculty with a growth mindset were more likely to see growth potential in struggling students and to support persistence to mastery. Teachers with growth mindset praised students for their effort rather than traits. They were also more likely to support school change efforts (King \& Shuford, 1996; Mueller \& Dweck, 1998; Yeager, Johnson, Spitzer, Trzesniewski, Powers, \& Dweck, 2014).

\subsection{School Growth Mindset Culture}

The variables of a school growth mindset compared favorably with several variables of the 
learning organization model of Open Systems including; principal and faculty openness to change, collective efficacy, and work locus of control that explained improved school outcomes (Hanson, Ruff, \& Bangert, 2016; Spector, 1988). The construct of school growth mindset culture seems also to be imbued by Senge's $(1990,2000)$ systems thinking model describing the influences on organizational learning through the administrator's behavior, the feedback loop, and collaborative behaviors toward goal setting. In sum, a review of the literature revealed school growth mindset culture compared favorably with social cognitive theory, learning organization theory, and themes found in the literature on improving schools (Delaney, Dweck, Murphy, Chatman, \& Kray, 2015; Farrington et al., 2012; Murphy \& Dweck, 2010; Shannon \& Bylsma, 2007).

Applying growth mindset theory to develop growth mindset cultures in schools could increase teacher skills to support student psychosocial needs leading to the development of academic skills. School mindset interventions aim to develop the faculty belief that their school can help all students grow and learn (Blackwell, 2012; Farrington, 2013; Yeager \& Walton, 2011). Teachers with growth mindset beliefs were more open to new information and demonstrated increased ability to resolve a conflict. They showed more tolerance, chose learning goals over performance goals, demonstrated persistence and resilience in the face of obstacles, and exhibited reduced stereotype behaviors (Briceño, 2013; Gay, 2010; Sprengel \& Spritts, 2012; Yeager et al., 2014).

Current research is reporting the role an organization's values play in influencing the individuals' beliefs and behaviors within the organization (Dweck, 2010; Hoy et al., 1991; Tarter \& Hoy, 2004). The role of a school growth mindset culture has been increasingly discussed in the literature on educational leadership and is a critical part of this body of research. Research results showed when faculty participated in professional development on growth mindset this resulted in increased reports of teacher belief in growth that had a lasting effect; influencing faculty and administrators' subsequent behaviors (Gay, 2010).

\subsection{Developing a School Growth Mindset Culture}

Administrators can share information with faculty about their potential to change and grow through effort and learning. When school organizations acted according to the belief that individuals can grow and learn this resulted in the development of growth mindsets in their students (Blackwell et al., 2007; Briceño, 2013; Farrington et al., 2012; Sprengel \& Spritts, 2012; Yeager et al., 2012). Strategies promoting the development of faculty and student agency in schools were also found useful in promoting school growth mindsets (Blackwell, 2012).

\subsection{Psychosocial Skill Recommendation}

Recommendations for supporting student choice to engage in academic behaviors include developing a school growth mindset culture and teacher training that supports the development of students' psychosocial skill development. Psychosocial skills include increased "self-awareness, self-management, social awareness, relationship skills, and responsible decision-making" (Farrington et al., 2012, p. 49). Students with strong 
psychosocial skills showed improved social behaviors, autonomy, engagement, persistence toward academic goals, and reduced emotional stress (Bandura, 1997, 2001; Briceño, 2013; Greenberg, Weissberg, O’Brien, Zins, Fredericks, Resnik, \& Elias, 2003; Vygotsky, 1962, 1978). When schools have a growth mindset culture the faculty acts according to the belief that all teachers in the school can help all students in the school grow and learn. This increases the group's willingness to choose challenging organizational goals and leads to school improvement (Blackwell, 2012; Delaney et al., 2015; Dweck, 1986, 2010, 2012).

\section{Methods}

This study included a quantitative research design using SPSS version 22 analytical software (IBM, 2013) to perform a correlation analysis of variables and a multiple regression analysis of significantly correlated variables. Data collection used a combination of paper-based and online Likert-style surveys distributed to a stratified random sample of approximately 15 PK-12 school districts across a large northwestern state. Data was analyzed to determine covariance, correlations, with an analysis of variance.

\subsection{Participants}

The participants included faculty and administrators $(n=347)$ from a stratified random sample of 30 PK-12 schools across a large northwestern state. The sample was selected from a total population of 417 school districts including 10,153 teachers and 142,349 students during the 2014/2015 school year (Meador, 2015). A sample of schools, by class size, was selected through random number generator to obtain a representative sample. This sample size provided a $95 \%$ confidence level and a 5.16 confidence interval indicating the results of this study would generalize to the population under study. Table 1 in Appendix A shows the distribution of the stratified random sample.

Table 1. Table of the percent of public schools by size categories and number of responses collected

\begin{tabular}{|l|l|l|l|l|l|l|l|}
\hline \multirow{2}{*}{ Calculation } & \multicolumn{5}{|c|}{ Categories by Student Enrollment } & \multirow{2}{*}{ CL } & \multirow{2}{*}{ CI } \\
\cline { 2 - 7 } & $<150$ & 150 to 500 & 501 to 1000 & $>1000$ & Total & & \\
\hline Percent of total student population enrolled & $17 \%$ & $12 \%$ & $23 \%$ & $48 \%$ & $100 \%$ & & \\
\hline Actual number of responses collected & 45 & 73 & 122 & 107 & 347 & $95 \%$ & 5.16 \\
\hline Percentage of total responses collected & $13.0 \%$ & $21.0 \%$ & $35.2 \%$ & $30.8 \%$ & $100 \%$ & & \\
\hline
\end{tabular}

Note. $\mathrm{CL}=$ confidence level, $\mathrm{CI}=$ confidence interval.

\subsection{Instruments}

Data for this study was collected using a demographic questionnaire and the 20-item Likert-style WMSM scale that operationalizes the construct of a school's growth mindset 
culture (Blackwell, 2012). The scale used in this study asks respondents to rate their level of agreement on items ranging from $1=$ Strongly Disagree, $2=$ Disagree, $3=$ Somewhat Disagree, $4=$ Somewhat Agree, $5=$ Agree, and $6=$ Strongly Agree. A school growth mindset culture was described by Blackwell (2012) as a culture with a, "common vision, sharing knowledge, support, and resources," (Blackwell, 2012, para. 6-10). Hanson, Bangert and Ruff (2016) provided empirical evidence for three subfactors of the uni-dimensional construct of a school growth mindset culture operationalized on the WMSM scale including: shared leadership, collaborative planning, and open communication \& support.

\subsubsection{Collaborative Planning (CP)}

Collaborative planning was comprised of items 11-16. The items comprising this factor all related to formal structures within the system providing opportunities for teachers and administrators to collaborate through observation, shared planning, and feedback to improve instruction. The internal consistency reliabilities for CP was .89.

\subsubsection{Shared Leadership (SL)}

Shared leadership included items 1-5. The items included in this factor related to teacher and administrator engagement in collaborative decision-making processes. The internal consistency reliabilities for SL was .88 .

\subsubsection{Open Communication \& Support (OCS)}

The third factor consisted of items 6-10,17 and 19. The items were related to teachers and administrators' participation in informal activities to support student instruction and individual goals. The internal consistency reliabilities for OCS was .73.

\subsubsection{Scale Reliabilities and Construct Validity studies}

The internal consistency reliabilities for the WMSM was .92. The constructs captured on the WMSM scale were empirically tested and shown to significantly correlate with open systems organizational learning variables of openness to change, work locus of control, collective efficacy, goal alignment, and organizational citizenship behaviors (Hanson, 2015; Hanson, in progress a; Hanson, Bangert, \& Ruff, 2016). Appendix 1 includes the items on the WMSM scale.

\section{Results of the Analyses}

\subsection{One-Way ANOVA}

Results from a one-way analysis of variance (ANOVA) revealed that the elementary school What's My School Mindset mean scores were significantly higher than those for middle school $(p<.001, \mathrm{~d}=1.80)$ and high school teachers $(p<.001, d=1.20)$. The effect sizes (Cohen's d) for these comparisons ranged from moderate to large. However, there were no significant differences in WMSM mean scores when comparing elementary teachers to teachers in combined schools levels represented by PK-12, elementary/middle and high school/middle. Table 2 shows the WMSM means by school level and standard deviations. 


\section{Macrothink}

Table 2. ANOVA results Pearson correlations between building levels and standard deviations

\begin{tabular}{|l|l|l|l|}
\hline School Level & $n$ & $M$ & $S D$ \\
\hline Pk-12 & 31 & 4.29 & .82 \\
\hline Elementary & 112 & 4.65 & .72 \\
\hline Middle & 56 & 4.18 & .80 \\
\hline High School & 95 & 3.87 & .67 \\
\hline Elementary /Middle & 25 & 4.27 & .68 \\
\hline Middle/High School & 28 & 4.23 & .50 \\
\hline
\end{tabular}

\subsection{Regression Analysis}

Results of a multiple linear regression analysis, although significant, found that school level explained only about $5.2 \%$ of the variance in school mindset scores $\left(\mathrm{F}_{(1,347)}=19.112 ; p\right.$ $<.001)$. Although these results suggest that a small, yet significant, variation in teachers' WMSM scores is explained by school level, results from the ANOVA show that this variability in WSMS mean scores is primarily due to differences found when comparing elementary teacher WMSM means to middle and high school WMSM teacher means. Though there was a statistically significant difference between school WMSM mean by school size, there was a no statistically significant interaction effect between school level and school size. Figures 1 shows the graph of the WMSM mean scores by school level. 


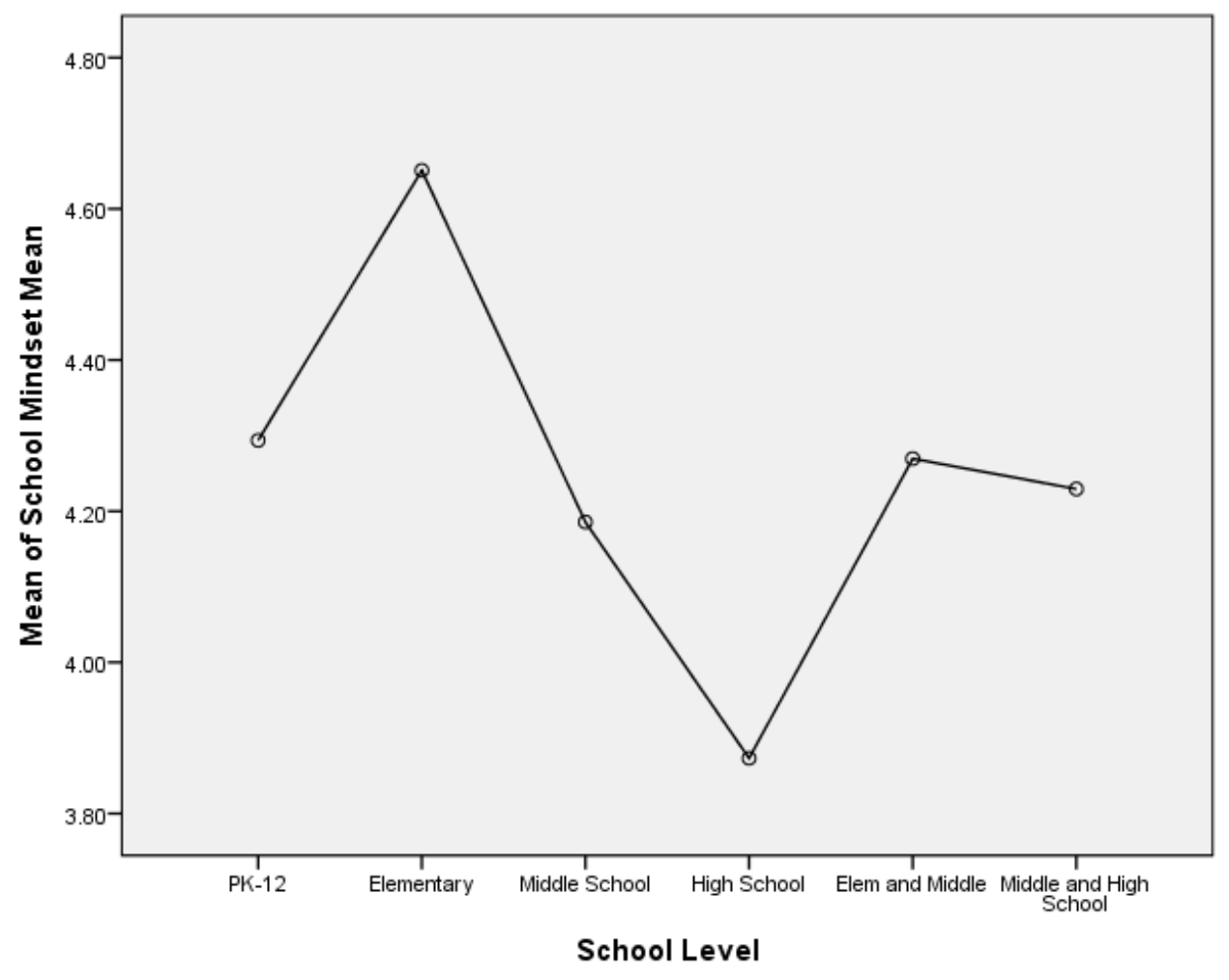

Figure 1. WMSM Means Plot by School Level (two-tailed test)

\subsection{Discussion of the Results}

The results of this study provide empirical evidence that a difference exists in faculty self-reports of their school culture between secondary and elementary school levels. When a school has a growth mindset culture, administrators and teachers interact in informal and formal structures that support each other, students, and the organization. A reduction in planning, sharing, and supporting behaviors is indicated by the significantly lower WMSM mean scores in secondary level schools than in elementary. The items of the WMSM scale suggest a reduction in teacher to teacher interaction, such as co-planning, and a reduction in teacher and administrator interaction, such as a reduction in collaborative decision-making.

Further, because openness to change, work locus of control, collective efficacy, and organizational citizenship behaviors have been shown to correlate with a WMSM culture, these faculty and administrative behaviors may be less likely occurring at the secondary level schools than in elementary. The reduction in these variables can theoretically be explained in part by teacher silos in single-subject matter classrooms, larger class sizes, increased student loads, and reduced parent participation at the secondary level; resulting in less opportunity to develop teacher peer, parent, and student relationships (Dwyer \& Hecht, 2001). Results indicate lowered expectations, performance-based instructional strategies, and fixed mindsets toward students' abilities to learn and grow in secondary-level teachers.

Students experience physiological and psychological changes during the maturation that 
occur during the teenage years with heightened self-consciousness about one's self-image and increased social awareness. This change in student behaviors needs an increase in teacher supportive behaviors for students. However, research suggests secondary level teachers lack the necessary training or preparation to meet student needs with the psychosocial supports students. Teachers in secondary schools were also shown to engage in behaviorist strategies of discipline, a teaching practice associated with fixed mindset beliefs (Akkerman \& Bakker, 2011, p. 138; Eccles \& Wigfield, 2002; Farrington et al., 2012, p. 63).

\section{Conclusion}

The results of this study revealed school level explained a significant difference in a school's growth mindset mean as quantified in teacher and administrator self-reports on the What's My School Mindset? Scale (Mindset Works, Inc., 2015c). This study provides support for the literature that differences exist between school culture and teacher behaviors at the elementary and secondary school levels (Farrington et al., 2012; Blackwell et al., 2007). Akkerman and Bakker (2011) wrote boundaries can be "potential learning resources rather than barriers" (p. 137). Confrontation of "some lack or problem that forces the intersecting worlds to reconsider their current practices and interrelations" is required for transformation to occur.

\subsection{School Growth Mindset Culture Implications}

The results of this study could be used to create opportunities for faculty dialogue and reflection that "develops an expanded sense of perspectives...that informs future practice" (Akkerman \& Bakker, 2011, p. 146). The results of this study may also provide realistic ways to implement change by using research-based evidence to challenge assumptions and give sound reasons for new practices (Ruff, 2002; Sanders \& Sheldon, 2009).

Research-based data, as collected on the WMSM scale, may provide additional paths for administrators to encourage faculty to collaborate on new ways to support students during school level transitions that increases student success and school completion rates (Delaney et al., 2015; Dweck, 2010, 2012; Farrington et al., 2012; Farrington, 2013; Kearney, 2007; McGrew, 2011). Administrators can use the WMSM scale as a boundary object to capture and quantify their school's culture and to develop interventions that recognize the unique individual and school needs of their school context. School growth mindset culture interventions include opportunities for faculty to participate in the decision-making and change processes, professional development that targets the development of teachers' psychosocial skills supporting student academic skills, and scheduled time for professional collaboration (Hanson, Bangert, \& Ruff, 2016).

Key strategies important to the development of teachers' skills include providing professional development and support embedded in the work day that promote teaching skills at providing students with psychosocial supports. Teachers can learn to reflect on one's own mindset and how one's epistemologies influence teacher choice of pedagogies and expectations of students. Administrators can develop school structures to support teacher to teacher interactions, teacher to administrator interaction, teacher to parent interactions, and 
parent/student interactions in support of academic behaviors such as homework completion, study habits, and school attendance.

\subsection{Limitations}

This study explored the perceptions of teachers and administrators in a large, predominantly rural, white demographic, northwestern state of the U.S. The study design included a stratified random sample of schools representing approximately similar size, level, and demographics of the PK-12 public schools in the state. However, respondents to the surveys included a slightly larger representation of schools in the category under 1,000 student enrollment than was actual for school enrollments in that state. Table 1 shows statistics for comparison of the school size with the state actual percentage of enrollment by school enrollment. This study was performed in a single state and may not generalize to other state school populations that have different demographics of school sizes, urbanicity, or diverse populations. School classification had a significant effect on school growth mindset mean and may influence the faculty's perceptions of their school's ability to help students learn and grow.

\subsection{Suggestions for Future Research}

Future studies could include a qualitative study design to explore and develop a rich thick understanding of differences in teacher and student psychosocial skills, implicit theories, and behaviors between elementary, middle, and high school contexts, and between school sizes. A quantitative study to explore the correlation between teachers' epistemological beliefs at differing school levels, student academic behaviors, and student non-academic behaviors might reveal further variables to explore. Regression analyses of variables might provide empirical evidence explaining how differences in school level impact teacher's perceptions and beliefs about their school's ability to help all students learn and grow. Understanding the influence of school transitions on students and the effect of teacher beliefs in their school's ability to help students' develop non-cognitive skills could provide insights to develop programs for teacher development. Finally, research suggests that measures of a school's growth mindset at boundary crossings of elementary to middle school, middle to high school, and high school to college and work are an important and warranted area for further study.

\section{References}

Akkerman, S., \& Bakker, A. (2011). Boundary crossing and boundary objects. Review of Educational Research, 81(2), 132-169. http://dx.doi.org/10.3102/0034654311404435

Allensworth, E. M., \& Easton, J. Q. (2005). The on-track indicator as a predictor of high school graduation. Chicago: University of Chicago Consortium on Chicago School Research. Retrieved from https://consortium.uchicago.edu/sites/default/files/publications/p78.pdf

Argyris, C. (1999). On organizational learning. Cambridge, MA: Harvard University Press.

Argyris, C., \& Schon, D. (1996). Organizational Learning II: Theory, method and practice. Reading, Massachusetts: Addision Wesley Publishing. 
Austin, S., \& McCann, R. (March, 1992). Here's another arbitrary grade for your collection: A state-wide study of grading policies (ERIC Document Reproduction Service No. 343 944). Paper presented at the Annual Meeting of the American Educational Research Association, San Francisco, CA.

Bandura, A. (1977). Social learning theory. Englewood Cliffs, N.J.: Prentice-Hall.

Bandura, A. (1986). Social foundations of thought and action: A social cognitive theory. Englewood Cliffs, N.J.: Prentice-Hall.

Bandura, A. (1989). Regulation of cognitive processes through perceived self-efficacy. Developmental Psychology, 25(5), 729-735. http://dx.doi.org/10.1037/0012-1649.25.5.729

Bandura, A. (1997). Self-efficacy: The exercise of control. New York: Freeman.

Bandura, A. (2001). Social cognitive theory: An agentic perspective. Annual Review of Psychology, 52, 1-26. http://dx.doi.org/10.1146/annurev.psych.52.1.1

Blackwell, L. (March 28, 2012). Developing a growth mindset school culture. Retrieved from http://community.mindsetworks.com/developing-a-growth-mindset-school-culture

Blackwell, L. S., Trzesniewski, K. H., \& Dweck, C. S. (2007). Implicit theories of intelligence predict achievement across an adolescent transition: A longitudinal study and an intervention. Child Development, 78(Study 1), 246-263. http://dx.doi.org/10.1111/j.14678624.2007.00995.x

Blackwell, L., Trzesniewski, K., \& Dweck, C. S. (January 1, 2011). In C. Dweck (Eds.), Mindset Works ${ }^{\circledR}$ : Student Motivation through a Growth Mindset. Retrieved from http://www.mindsetworks.com/default.aspx

Briceño, E. (July 28, 2014). Mindsets and student agency. Competency Works. Retrieved from http://www.competencyworks.org/analysis/mindsets-and-student-agency/

Capper, C. A., \& Green, T. L. (2013). Organizational theory and the development of leadership capacity for integrated, socially just schools. In L. C. Tillman, \& J. J. Scheurich (Eds.), Handbook of research on educational leadership for equity and diversity (pp. 62-82).

New York: Routledge. http://dx.doi.org/10.4324/9780203076934.ch4

Cheng, E. C. (2011). The role of self-regulated learning in enhanced learning performance. The International Journal of Research and Review, 6(1), 1-16.

Corrigan, P., \& Frith, R. (1976). The politics of youth culture. In S. Hall \& T. Jefferson (Eds.), Resistance through rituals: Youth subcultures in post-war Britain (pp. 231-242). Birmingham, UK: University of Birmingham.

Cross, L. H., \& Frary, R. B. (1999). Hodgepodge grading: Endorsed by students and teachers alike. Applied Measurement in Education, 12(1), 53-72. http://dx.doi.org/10.1207/s15324818 ame1201_4

Delaney, S., Dweck, C., Murphy, M., Chatman, J., \& Kray, L. (January 1, 2015). New study 
findings: Why fostering a growth mindset in organizations matters. Retrieved from http://senndelaney.com/SD_growthmindsetstudy.html

Dweck, C. (1986). Motivational processes affecting learning. American Psychologist, 41(10), 1040-1048. http://dx.doi.org/10.1037/0003-066X.41.10.1040

Dweck, C. S. (1999). Self-theories: Their role in motivation, personality and development. Philadelphia: Psychology Press

Dweck, C. S. (2002). Beliefs that make smart people dumb. In R. J. Sternberg (Ed.), Why smart people do stupid things. New Haven, CT: Yale University Press.

Dweck, C. S. (2008). Mindset: The new psychology of success. New York: Ballantine Books.

Dweck, C. S. (2010). Mind-sets and equitable education. Principal Leadership, 26-29. Retrieved from http://www.principals.org/Content.aspx?topic $=61219$

Dweck, C. S. (2012). Mindsets and human nature: Promoting change in the Middle East, the schoolyard, the racial divide, and willpower. American Psychologist, 67(8), 614-622. http://dx.doi.org/10.1037/a0029783

Dweck, C. S., \& Leggett, E. L. (1988). A social-cognitive approach to motivation and personality. Psychological Review, 95(2), 256-273. http://dx.doi.org/10.1037/0033-295X. 95.2.256

Dweck, C. S., Chiu, C., \& Hong, Y. (1995). Implicit theories and their role in judgments and reactions: A word from two perspectives. Psychological Inquiry, 6(4), 267-285. http://dx.doi.org/10.1207/s15327965pli0604_1

Dwyer, D. J., \& Hecht, J. B. (2001). Minimal Parental Involvement. School Community Journal, 11(1), 275-290. Retrieved from http://www.adi.org/journal/ss01/Chapters/Chapter 20-Dwyer\&Hecht.pdf

Eccles, J. S., \& Midgley, C. (1989). Stage/environment fit: Developmentally appropriate classrooms for early adolescents. In R. E. Ames \& C. Ames (Eds.), Research on motivation in education (Vol. 3, pp. 139-186). San Diego, CA: Academic Press.

Eccles, J. S., \& Wigfield, A. (2002). Motivational beliefs, values, and goals. Annual Review of Psychology, 53, 109-32. http://dx.doi.org/10.1146/annurev.psych.53.100901.135153

Eccles, J. S., Lord, S., \& Midgley, C. (1991). What are we doing to early adolescents? The impact of educational contexts on early adolescents. American Journal of Education, 99(4), 521-542. http://dx.doi.org/10.1086/443996

Edwards, R., \& Fowler, Z. (2007). Unsettling boundaries in making a space for research. British Educational Research Journal, 33, 107-123. http://dx.doi.org/10.1080/0141192060 1104565

Esses, V. M., Haddock, G., \& Zanna, M. P. (1993). Values, stereotypes, and emotions as determinants of intergroup attitudes. In D. M. Mackie \& D. L. Hamilton (Eds.), Affect, 
cognition and stereotyping: Interactive processes in group perception (pp. 137-166). San Diego: Academic Press. http://dx.doi.org/10.1016/B978-0-08-088579-7.50011-9

Farrington, C. (April 1, 2013). Academic mindsets as a critical component of deeper learning. A White Paper prepared for the William and Flora Hewlett Foundation. University of Chicago Consortium on Chicago School Research. Retrieved from http://www.hewlett.org/ library/academic-mindsets-as-a-critical-component-of-deeper-learning/

Farrington, C. A., Roderick, M., Allensworth, E., Nagaoka, J., Seneca-Keyes, T. S., Johnson, D. W., \& Beechum, N. O. (2012). The role of noncognitive factors in shaping school performance: A critical literature review. Teaching adolescents to become learners. Chicago: University of Chicago Consortium on Chicago School Research. Retrieved from https://consortium.uchicago.edu/sites/default/files/publications/Noncognitive\%20Report.pdf

Gay, G. (2010). Culturally responsive teaching theory, research, and practice. New York, NY: Teachers College Press.

Greenberg, M. T., Weissberg, R. P., O’Brien, M. U., Zins, J. E., Fredericks, L., Resnik, H., \& Elias, M. J. (June/July, 2003). Enhancing school-based prevention and youth development through coordinated social, emotional, and academic learning. American Psychologist, 58(6-7), 466-474. http://dx.doi.org/10.1037/0003-066X.58.6-7.466

Hall, G. E., \& Hord, S. M. (2015). Implementing change: Patterns, principles, and potholes (4th ed.). Boston: Pearson.

Hanson, J. L. (2015). Determination and validation of the "What's My School Mindset?" instrument factor structure (Order No. 3722197). Dissertations \& Theses at Montana State University; ProQuest Dissertations \& Theses Global.

Hanson, J. L. (in progress a). A replication study of the validation of the What's My School Mindset? survey.

Hanson, J. L. (in progress b). Measuring student perceptions of non-cognitive factors to develop student agency for academic behaviors.

Hanson, J., Bangert, A., \& Ruff, W. (2016). A validation study of the What's My School Mindset? survey. Journal of Educational Issues, 2(2), 244-266. http://dx.doi.org/10.5296/ jei.v2i2.10138

Haslam, S. A., Reicher, S. D., \& Platow, M. J. (2011). The new psychology of leadership: Identity, influence and power. New York: Psychology Press.

Hoy, W. K., \& Sweetland, S. R. (2001). Designing better schools: The meaning and measure of enabling school structures. Educational Administration Quarterly, 37(3), 296-321. http://dx.doi.org/10.1177/00131610121969334

Hoy, W., Tarter, C., \& Kottkamp, B. (1991). Open schools/healthy schools measuring organizational climate. Newbury Park: Sage Publications.

IBM Corporation. (2013). IBM SPSS Statistics for MacIntosh (Version 22.0). Armonk, NY: 
IBM Corporation.

Kearney, S. (2007). Principal Influence: A Study of Its Effect on School Change. The University of Texas at San Antonio: ProQuest.

King, P., \& Shuford, B. (1996). A multicultural view is a more cognitively complex view: Cognitive development and multicultural education. American Behavioral Scientist, 40(2), 153-164. http://dx.doi.org/10.1177/0002764296040002006

Lacey, C. (1970). Hightown grammar: The school as a social system. Manchester, UK: Manchester University Press.

Mays, J. B. (1965). Education and the urban child. Liverpool, UK: Liverpool University Press.

McGrew, K. (2011). A review of class-based theories of student resistance in education: Mapping the origins and influence of learning to labor. American Educational Research Association, 81(2), 234-266. http://dx.doi.org/10.3102/0034654311402358

Meador, D. (2015). Profile on Montana education and schools. Retrieved from http://teaching.about.com/od/ProfilesInEducation/a/Montana-Education.htm

Middleton, H. E., \& Baartman, L. K. J. (Eds.). (2013). Transfer, Transitions and Transformations of Learning. Rotterdam, The Netherlands: Sense Publishing. http://dx.doi.org/10.1007/978-94-6209-437-6

Mindset Works, Inc. (2008-2012b). Dr. Dweck's discovery of fixed and growth mindsets have shaped our understanding of learning. Retrieved October 26, 2016, from http://www.mindsetworks.com/webnav/whatismindset.aspx

Mindset Works, Inc. (2015a). In C. Dweck (Ed.), About Us - Mindset Works ${ }^{\circledR}$ : Student Motivation through a Growth Mindset. Retrieved from http://www.mindsetworks.com/ webnav/about.aspx

Mindset Works. (2015c). What's My School Mindset? (Para. 5). Retrieved October 26, 2016, from https://www.mindsetworks.com/assess/

Mueller, C. M., \& Dweck, C. S. (1998). Praise for intelligence can undermine children's motivation and performance. Journal of Personality and Social Psychology, 75, 33-52. http://dx.doi.org/10.1037/0022-3514.75.1.33

Oakes, J., Welner, K., \& Renée, M. (2015). Public scholarship to educate diverse democracies. Paper presented at the Annual Meeting of the American Educational Research Association. Retrieved from http://www.aera.net/EventsMeetings/AnnualMeeting/2016 AnnualMeetingTheme/tabid/15861/Default.aspx

PERTS-Raising Academic Achievement. (January 1, 2014a). Retrieved March 15, 2015, from https://www.perts.net/

PERTS-Raising Academic Achievement. (January 1, 2014b). Retrieved March 15, 2015, from 
https://www.perts.net/challenge

Ruff, W. (2002). Constructing the role of instructional leader: The mental models of urban elementary school principals (Doctoral dissertation). The University of Texas at San Antonio.

Sanders, M., \& Sheldon, S. (2009). Principals matter: A guide to school, family, and community partnerships. Thousand Oaks, CA Corwin.

Senge, P. (2000). Schools that learn: A fifth discipline fieldbook for educators, parents, and everyone who cares about education. New York: Doubleday.

Senge, P. M. (1990, revised 2006). The fifth discipline: The art \& practice of the learning organization. New York: Doubleday.

Shannon, G. S., \& Bylsma, P. (2007). Nine characteristics of high-performing schools (2nd ed.). Office of Superintendent of Public Instruction, Olympia, WA. Retrieved from http://www.k12.wa.us/research/pubdocs/NineCharacteristics.pdf

Shor, I., \& Freire, P. (1987). A pedagogy for liberation: Dialogues on transforming education. Boston, MA: Bergin and Garvey.

Spector, P. E. (1988). Development of the work locus of control scale. Journal of Occupational Psychology, 61, 335-340. http://dx.doi.org/10.1111/j.2044-8325.1988.tb00 470.x

Sprengel, M., \& Spritts, M. (June 12, 2012). OA13.02. Utilizing mind-body practices in public schools: Teaching self-regulation skills and fostering resilience in our next generation. BMC Complementary and Alternative Medicine. http://dx.doi.org/10.1186/1472-6882-12$\mathrm{S} 1-\mathrm{O} 50$

Suchman, L. (1994). Working relations of technology production and use. Computer Supported Cooperative Work, 2, 21-39. http://dx.doi.org/10.1007/BF00749282

Tarter, C., \& Hoy, W. (2004). A systems approach to quality in elementary schools: A theoretical and empirical analysis. Journal of Educational Administration, 42(5), 539-554. http://dx.doi.org/10.1108/09578230410554052

Vygotsky, L. S. (1962). Thought and language. Cambridge, Massachusetts: Institute of Technology: M.I.T. Press. http://dx.doi.org/10.1037/11193-000

Vygotsky, L. S. (1978). Mind in society: The development of higher psychological processes. Cambridge, MA: Harvard University Press.

Wenger, E. (1998). Communities of practice, learning, meaning and identity. Cambridge, UK: Cambridge University Press. http://dx.doi.org/10.1017/CBO9780511803932

Willis, P. (1977/1981). Learning to labor: How working class kids get working class jobs (Original work published in 1977). New York, NY: Columbia University Press.

Yeager, D. S., \& Walton, G. M. (2011). Social-psychological interventions in education: They're not magic. Review of Educational Research, 81, 267. http://dx.doi.org/10.3102/ 
0034654311405999

Yeager, D. S., Johnson, R., Spitzer, B. J., Trzesniewski, K. H., Powers, J., \& Dweck, C. S. (2014). The far-reaching effects of believing people can change: Implicit theories of personality shape stress, health, and achievement during adolescence. Journal of Personality and Social Psychology, 106(6), 867-884. http://dx.doi.org/10.1037/a0036335

Yeo, R. (2005). Revisiting the roots of learning organization: A synthesis of the learning organization literature. The Learning Organization, 12(4), 368-382. http://dx.doi.org/10.1108/ 09696470510599145

Zimmerman, B. J. (1989). A social cognitive view of self-regulated learning. Journal of Educational Psychology, 81, 329-339. http://dx.doi.org/10.1037/0022-0663.81.3.329

\section{Appendix}

Appendix 1. What's My School Mindset (WMSM) Survey

Scale: Never $=1$, Rarely $=2$, Sometimes $=3$, Frequently $=4$, Usually $=5$, Always $=6$

1. Leadership opportunities are open to all staff members and staff members are invited to participate periodically throughout the school year.

2. We have systems where teachers are directly involved and participate in decision-making and planning for site initiatives.

3. Administration and leaders communicate decision-making strategies with staff and elicit their input.

4. Staff are able to put ideas "on the table" and "take them off" safely during planning, collaboration, and decision-making meetings.

5. Teachers are invited to give critical feedback about administrative practices and how they would like additional support.

6. Staff members are reluctant to work with or support new or struggling teachers. [Reverse-scored]

7. Teachers observe one another and give each other feedback to develop the team's best practices.

8. We have exclusive cliques or "camps" within our faculty. [Reverse-scored]

9. Teachers collaborate regularly, sharing or co-developing lessons, assessments, and student work.

10. Our teachers tend to protect or guard our lessons, strategies, tests, etc. from one another. [Reverse-scored]

11. Instructional expectations, standards, and evaluation protocols are made clear to teachers 
in advance.

12. Administrators communicate a sincere belief that staff members can develop their teaching skills with practice and feedback.

13. Teachers receive clear feedback on and ongoing support for their practice outside of formal evaluations.

14. Teachers, coaches, and administrators work together to design goals and plans for teacher development.

15. Teachers receive professional development that is targeted to their professional needs and goals.

16. Time is provided in the work day for coaching, co-planning/co-teaching, and structured professional learning.

17. Administrators and teachers in our school truly believe that they can help all students to meet learning goals.

18. There are structures for teachers and administrators to share information and work together to meet the specific needs of individual students.

19. There is an "us against them" feeling between teachers and students. [Reverse-scored]

20. We review our current state and set improvement goals for both the short and long-term.

Mindset Works, Inc. (2015c)

\section{Copyright Disclaimer}

Copyright for this article is retained by the author(s), with first publication rights granted to the journal.

This is an open-access article distributed under the terms and conditions of the Creative Commons Attribution license (http://creativecommons.org/licenses/by/3.0/). 